\title{
Psychological Background of the Connection between Learner's Autonomy and Motivation
}

\section{Психологічні основи зв'язку між автономією студента і мотивацією учіння}

\section{Ernest Ivashkevych}

Ph.D. in Psychology, Assistant Professor of the Department of Practice of English, the Translator, Rivne State University of the Humanities, Rivne (Ukraine)

ORCID ID: https://orcid.org/0000-0001-7219-1086

Researcher ID: http://www.researcherid.com/rid/F-3865-2019

E-mail: ivashkevych.ee@gmail.com

\section{Ернест Івашкевич}

Кандидат психологічних наук, старший викладач кафедри практики англійської мови, перекладач, Рівненський державний гуманітарний університет, м. Рівне (Україна)

\section{ABSTRACT}

The aim of this research is to show the connection between learner's autonomy and motivation, to provide the research of the substructures of the motivational component of professional competence of students.

Methods of the research. As for general scientific methods, in particular the method of induction, deduction, analysis and synthesis, comparative and descriptive methods and explanatory ones were used in the research. Also we used experimental method: the ascertaining research. The following psycho-diagnostic questionnaires were used: the questionnaire "Who am I?» (M. Kuhn and T. McPartland), the questionnaires "My way to the profession» and the tech-

Address for correspondence, e-mail: kpnu_lab_ps@ukr.net Copyright: (C) Ivashkevych Ernest

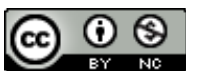
The article is licensed under CC BY-NC 4.0 International (https://creativecommons.org/licenses/by-nc/4.0/)

(C) Ivashkevych Ernest

DOI (article): https://doi.org/10.32626/2227-6246.2021-52.84-105 
nique "A pyramid of professional growth», the questionnaire of $H$. Heckhausen "Motivational tendencies of the person".

The results of the research. It should be noted that the vast majority of students in experimental and control groups considered it necessary to appreciate the professional motives of educational activities, although in fact few of them seriously considered the capabilities of a highly qualified specialist with foreign language and skills. Since the professional motives of educational activities contribute to the achievement of the ultimate goals of learning, motivation will greatly facilitate the formation of persons' professional orientation.

The educational and cognitive motives are more important for students: to study successfully, to receive good and high grades in academic subjects, to be constantly ready for classes. In this case, it should be noted that for students with good language skills, these motives are less significant than for students with low levels of language skills. This can be explained by the fact that the student feels more confident in terms of success in learning a foreign language. Others try to correct their situation and close the gaps in knowledge that are appeared for one reason or another one during the study of a foreign language at school.

Conclusions. The professional development of a future specialist is a complex integrative process that involves the use of various forms, tools and methods of facilitative influence on a student's personality. In order to select and justify the feasibility of using such forms, tools and methods, etc., we describe a conceptual model of the professional development of a future specialist. This model, in turn, requires special development, description and analysis of its constituents due, first of all, to its integrity, multicomponent and polyfunctionality.

The sense of the category "professional development" can be found in the paradigm of its comparison with the fundamental scientific categories "the development" and "the formation". The development is defined as the objective process of internal consistent quantitative personal change. Professional development involves the inclusion of a person into the functioning of a new social environment, which is characterized by certain norms of communication, behavior, values, moral and ethical norms and some others. Interpersonal relationships that are developed in the professional team, largely determine the course of the professional adaptation of a man, the formation of his / her social status. Therefore, the components of the professional development should include socio-psychological features that determine a person's place in a professional group, his / her social status.

C Ivashkevych Ernest

DOI (article): https://doi.org/10.32626/2227-6246.2021-52.84-105 
DOI: https://doi.org/10.32626/2227-6246.2021-52

2021. випуск 52

Key words: learner's autonomy, motivation, interpersonal relationships, goals of learning, the formation of persons' professional orientation, professional development.

\section{Introduction}

Before we start exploring the connection between learner's autonomy and motivation, the term "motivation» has to be defined. Motivation is defined as the process that initiates, guides and maintains goal-oriented behavior. Motivation is what causes us to act, whether it is getting a glass of water to reduce thirst or reading a book to gain knowledge (Гончарук \& Онуфрієва, 2018). In such a way, motivation is highly valued for being in the core of biological, cognitive and social regulation.

People are moved to action by different types of factors. These are basically differentiated to extrinsic and intrinsic. R. Ryan and E. Deci consider the distinction between extrinsic and intrinsic motivation crucial (Ryan \& Deci, 2000). Comparisons between people whose motivation is authentic (literally, self-authored or endorsed) and those who are merely externally controlled for an action typically reveal that the former, relative to the latter, have more interest, excitement, and confidence, which in turn is manifested both as enhanced performance, persistence, and creativity (Ryan \& Deci, 2000: 69).

Let us show intrinsic motivation and learner's autonomy. As R. Ryan \& E. Deci claim humans are born with intrinsic motivational tendencies (Ryan \& Deci, 2000: 70). Children are keen to explore and learn without any external rewards during the early childhood. Therefore, the question is not how to cause intrinsic motivation, but how to sustain it.

In the Cognitive Evaluation Theory (CET) R. Ryan and E. Deci stated three main factors influencing intrinsic motivation (Ryan \& Deci, 2000: 68-78). These are relatedness, competence and autonomy. As R. Ryan and E. Deci found out the positive performance feedback (competence) enhances in(C) Ivashkevych Ernest

DOI (article): https://doi.org/10.32626/2227-6246.2021-52.84-105 
DOI: https://doi.org/10.32626/2227-6246.2021-52

2021. випуск 52

trinsic motivation only when it is accompanied by the sense of autonomy (Ryan \& Deci, 2000). People have not only to experience competence or efficacy, they have also to experience the behavior of others as self-determined for intrinsic motivation to be in evidence (Ryan \& Deci, 2000: 70).

On the contrary, perceived external locus of causality is represented by deadlines, threads, imposed goals, but also tangible rewards diminish intrinsic motivation. "In contrast, choice, acknowledgment of feelings, and opportunities for self-direction were found to enhance intrinsic motivation because they allow people a greater feeling of autonomy (Ryan \& Deci, 2000: 70).

To support intrinsic motivation there is the last but not the least aspect and it is relatedness. As R. Ryan \& E. Deci (Ryan \& Deci, 2000: 71) report a warm and supportive relationships between educator and learner are of immense importance. In the classes where the teacher was perceived as cold and not be caring the level of intrinsic motivation was significantly lower. As R. Ryan and E. Deci summarize all aforementioned principles apply only to intrinsic motivation, that is to the activities that are perceived as new, challenging or possessing an aesthetic value. In other cases we are driven by extrinsic motivation (Ryan \& Deci, 2000: 71).

Also we have to describe extrinsic motivation and learner's autonomy. We as teachers, strive for and are keen to support intrinsic motivation of our students because it is necessary to point out that not many actions in their and even our lives are motivated intrinsically. On the contrary, the further from the early childhood we are, the more extrinsic motivation appears. These are our parents, teachers, bosses, a society or laws that require a particular type of our behavior. These types of behaviors are usually not interesting and their values are not automatically adopted. According to R. Ryan and E. Deci, the question is to what degree the value and regulation of

(C) Ivashkevych Ernest

DOI (article): https://doi.org/10.32626/2227-6246.2021-52.84-105 
DOI: https://doi.org/10.32626/2227-6246.2021-52

2021. випуск 52

the requested behavior have been internalized and integrated (Ryan \& Deci, 2000: 71).

The terms «internalization» and «integration» play a central role in the theory of extrinsic motivation. "Internalization refers to people's "taking in" a value or regulation, and integration refers to the further transformation of that regulation submits into people's own so that it subsequently will emanate from their sense of Self (Ryan \& Deci, 2000: 71). R. Ryan and E. Deci puts forward that there are some perspectives that see extrinsic motivation and autonomy as contradictory phenomenon (Ryan \& Deci, 2000: 71). However, R. Ryan and E. Deci's Self Determination Theory proposes, that extrinsic motivation can vary greatly in its relative autonomy.

R. Ryan and E. Deci give some examples of a student doing homework either because the person realizes the value of education for his / her future career - which is totally extrinsically motivated as the person hopes he / she will get something for his / her action or a student who is just under his parents' control. Although both examples involve no real enjoyment, the former one can be considered autonomous behaviour as it includes personal endorsement and feeling of choice (Ryan \& Deci, 2000: 71).

To classify the range of different types and degrees of both extrinsic and intrinsic motivation and relevant processes, R. Ryan and E. Deci in their Organismic Integration Theory (OIT) developed the schema of The Self-Determination Continuum (Ryan \& Deci, 2000: 72). And there is a motivation. Learners are non-motivated, it means they do not act or act without intention, when they do not value the activity, do not feel competence to do it, or do not expect the activity to bring a desired outcome. According to this point we can see how fostering learner's autonomy may result in solving the problem of non-motivation. Making children aware of the processes either taking place in the classroom or when they are learning makes pupils more competent to take actions. Setting the goals can (c) Ivashkevych Ernest

DOI (article): https://doi.org/10.32626/2227-6246.2021-52.84-105 
DOI: https://doi.org/10.32626/2227-6246.2021-52

2021. випуск 52

help learners to see the value of school work and again makes them more competent - as it requires following their personal objectives. Fostering learner's autonomy may shift the locus of causality from «impersonal» to hopefully «internal» or at least «somewhat internal».

In the middle part of the schema (Ryan \& Deci, 2000: 71) described four degrees of extrinsic motivation varying in the extent to which the regulation is autonomous. The far left part represents the classic state of intrinsic motivation, the doing of an activity for its inherent satisfactions. It is highly autonomous and represents the prototypic instance of self-determination.

Despite being described in a kind of a progress way, R. Ryan and E. Deci pointed out that it was not necessary to go through all the stages of the continuum (Ryan \& Deci, 2000: 72). Rather, they [people] can relatively readily internalize a new behavioural regulation at any point along this continuum depending on both prior experiences and current situational factors.

R. Ryan and E. Deci illustrated the relationships between relative autonomy and extrinsic motivation in education by numerous examples of educational research (Ryan \& Deci, 2000). Some researchers tested the formulation that these different types of motivation, with their distinct properties, lie along a continuum of relative autonomy (Scharle \& Szabó, 2000). They investigated achievement behaviors among school children and found that external, introjected, identified, and intrinsic regulatory styles were intercorrelated according to a quasi-simplex pattern, thus providing evidence for an underlying continuum. Other studies in education extended these findings, showing that more autonomous extrinsic motivation was associated with more engagement, better performance, lower dropout, higher quality learning, and better teacher ratings, among other outcomes (Scharle \& Szabó, 2000).

In this article we'd like to tell about facilitating integration of external motivation. As we have learned, more autono(c) Ivashkevych Ernest

DOI (article): https://doi.org/10.32626/2227-6246.2021-52.84-105 
DOI: https://doi.org/10.32626/2227-6246.2021-52

2021. виПУСК 52

mously regulated extrinsic motivation brings a lot of advantages to both students and teachers. Thus, the issue of effective facilitating of integration of external motivation becomes highly important.

R. Ryan and E. Deci identified three main factors influencing successful internalization and integration (Ryan \& Deci, 2000: 73). According to this fact, these are the same factors that in a great degree influenced intrinsic motivation. The first factor is represented by relatedness. R. Ryan and E. Deci (2000: 74) assumed that since the actions people carried out when extrinsically motivated are not basically interesting, the primary reason they performed such actions because the behavior is prompted, modeled or valued by significant others to whom they feel (or want to feel) attached or related (Ryan \& Deci, 2000: 74). To put it simply, when children feel safe, connected to and cared for by both - parents and teachers, internalization and integration are more likely to be in evidence.

The second column of successful internalization and integration is undoubtedly competence: again the term mentioned in the chapter on intrinsic motivation. People are more likely to adopt activities that are relevant for social groups' value when they feel efficacious with respect to those activities. In this case with all intentional action, autonomy suggests that supports for competence should facilitate internalization (Ryan \& Deci, 2000: 73).

The last but not the least aspect which is supporting internalization and integration of external motivation is autonomy. The experience of autonomy is seen as some critical element for regulation to be in a great degree integrated (Ryan \& Deci, 2000: 74). It is possible to expect autonomous regulation if the context is autonomy supportive, it means allowing the person to feel competent, related, and autonomous. To integrate a regulation, people must grasp its meaning and synthesize that meaning with respect to their other goals and values. Such deep, holistic processing is facilitated by a sense of choice, (C) Ivashkevych Ernest

DOI (article): https://doi.org/10.32626/2227-6246.2021-52.84-105 
DOI: https://doi.org/10.32626/2227-6246.2021-52

2021. випуск 52

volition, and freedom from excessive external pressure toward behaving or thinking a certain way. In this sense, support of autonomy allows individual to transform values into their own ones actively (Scharle \& Szabó, 2000).

In this article a close relationship between autonomy and motivation will be described. We'll see that autonomy nurtures and it is nurtured by intrinsic motivation as well as it influences successful modes of internalization of extrinsic motivation. We'll see that one of the most important aspects influencing learners' motivation is a rapport between a teacher and a learner.

One of the most effective ways to promote learner's autonomy is using such kind of the activity as group work. Group work is the important part of the learner's autonomous classroom. By shifting the focus from teaching to learning and diminishing the learners' dependence on the teacher, the groundwork is laid for peer assistance. The connection between learner's autonomy and dependence means that at any particular time learners will be able to perform some tasks by themselves but they need help with others. Individual differences will ensure that learners develop their personality at different rates and with different emphases. This means that almost from the beginning learners will be able to support one another in task performances. This is why group work plays a key role from any psychological point of view. In the definition of the zone of proximal development the author relied on adults or more capable peers to take a role of a psychologist. By the principles of learner's autonomy relating to group work this role is assumed firstly by one learner and then another one in a complex structure of interdependence (Максименко, Ткач, Литвинчук \& Онуфрієва, 2019).

E. Batel indicates that in the autonomous classroom learners manage their group work by using their own resources (Batel, 2020). N. Mykhalchuk and E. Ivashkevych have built

(C) Ivashkevych Ernest

DOI (article): https://doi.org/10.32626/2227-6246.2021-52.84-105 
DOI: https://doi.org/10.32626/2227-6246.2021-52

2021. випуск 52

up some criteria that can be used when training learners in forming their own groups (Mykhalchuk \& Ivashkevych, 2019):

- learners are allowed to choose partners by their preferences, those they work well with or they think they can learn from;

- learners can choose partners they have seldom or never worked with before, which provides variety in the group work, helps learners get to know one another and prevent cliques;

- partners who have the same interests in different activities or by materials,

- partners who have certain abilities like good writing;

- partners who can provide peer tutoring.

At the end of each task all the group members, together with the teacher, assess a group work. This helps the learners make the connection between the goals they set collaboratively at the beginning, the strategies used to achieve the goals and understand the outcome, and put them into monologue- or dialogue-based speech. The learners assess their own contribution to solve the task and provide a group activity. The experiences having been accumulated by different groups are shared with the whole class and the teacher, and together they'll try to find solutions according to different problems and find out the most effective way to form groups.

At first the learners may form groups out of habit choosing to work with their friends, but as they get used to this format, different groups begin to appear. At the upper levels of providing the activities the following criteria are a good frame of reference:

1. "What do I want to be better at? Why?

2. What do I want to do? Why?

3. Who would I like to work with? Why?»

Learning how to choose working partners increases learners' awareness of, for example, their strengths, weaknesses and personal style of the activity.

(C) Ivashkevych Ernest

DOI (article): https://doi.org/10.32626/2227-6246.2021-52.84-105 
Successful group activity can boost learner's autonomy and help students to implement a different atmosphere in the classroom (Mykhalchuk \& Bihunova, 2019). A teacher has to be very much aware of how the group work is progressing and what steps are necessary. Poor group activity can do as much damage to morale as good group activity can help it. It is important for teachers to give learners all necessary opportunities to develop good group work habits and they may have to be active with the whole class regularly in setting up good group activities' principles.

According to these, the aim of this research is to show the connection between learner's autonomy and motivation, to provide the research of the substructures of the motivational component of professional competence of students.

\section{Methods of the research}

Taking into account the impotence of the conventional methods of scientific research while dealing with the object of our article, the most substantial part of the methodological base for this research has been developed by us. As for general scientific methods, such of them as the method of induction, deduction, analysis and synthesis, comparative and descriptive methods and explanatory ones were also used quite successfully.

This stage of the research has the goal at assessing the results of the substructures of the motivational component of professional competence of students. It is shown the direction of professional activity and professional expectations, also their autonomy.

Thus, this stage of the ascertainment research has the aim at assessing the motivational component of students' professional competence. At this stage of the research the following psycho-diagnostic questionnairies were used: the questionnaire «Who am I?» (M. Kuhn and T. McPartland) (Кун \& Макпартленд, (2019), the questionnairies «My way to the profession» and the technique "A pyramid of professional growth" 
DOI: https://doi.org/10.32626/2227-6246.2021-52

2021. випуск 52

(Варбан, 1998), the questionnaire of H. Heckhausen «Motivational tendencies of the person» (2019).

\section{Results and their discussion}

Motivation of learning activity is considered by us as a complex, multi-component and multi-stage process in which the volitional, cognitive and emotional structures of the individual are actualized. The motivational sphere of students is provided with motives of different content, from the desire to become a highly qualified specialist and ending with the desire not to upset their parents. It should be emphasized that quite often the distant perspective gives rise to deep and fully realized motives for learning. Also the most important is a person's attitude to his / her activity, and, accordingly, how he / she performs the process of the activity will largely be determined by how far the specialist sees the prospect of the tasks that lie before him / her.

To assess the formation of students' motivational sphere we used four groups of motives: 1) educational and cognitive motives (passion for studying a foreign language, translation activities, passing a foreign language qualification exam at B2 level or higher); 2) professional motives (acquisition of foreign language professional communicative competence, desire to become a highly qualified specialist); 3) motives for social identification (to achieve respect from teachers, to keep up with classmates in the learning outcomes, to avoid condemnation and criticism for poor learning by adults and socially significant people); 4) utilitarian motives (desire to work abroad, to improve their financial position through learning a foreign language, acquiring translation skills, constantly receiving a scholarship).

The results of the survey of students on the motives for learning a foreign language are given in Table 1 of Appendix B. The analysis of the results of the questionnaire made it pos(C) Ivashkevych Ernest

DOI (article): https://doi.org/10.32626/2227-6246.2021-52.84-105 
DOI: https://doi.org/10.32626/2227-6246.2021-52

2021. ВИПУСК 52

sible to identify the main motives of students' readiness for the performance of educational activities. They are characterized by the presence of motives with both near ones and far perspective motives. These are educational and cognitive motives (sign 3), professional ones (signs 1, 5), social identification motives (signs 11, 12), utilitarian ones (sign 9).

Table 1

The formation of motives of educational activity of students of experimental and control groups (by 7-point scale, $\mathrm{N}=303$ )

\begin{tabular}{|c|l|c|c|}
\hline \multirow{2}{*}{ № } & \multicolumn{1}{|c|}{ Motives } & The average score \\
\cline { 3 - 4 } & \multicolumn{1}{|c|}{$\begin{array}{c}\text { Experimen- } \\
\text { tal groups }\end{array}$} & $\begin{array}{c}\text { Control } \\
\text { groups }\end{array}$ \\
\hline 1. & $\begin{array}{l}\text { To become a qualified specialist with } \\
\text { knowledge of a foreign language }\end{array}$ & 5.8 & 5.7 \\
\hline 2. & I like learning a foreign language & 6.2 & 6.1 \\
\hline 3. & Successfully study and pass the exams & 5.5 & 5.8 \\
\hline 4. & $\begin{array}{l}\text { Successfully pass the qualifying exam in } \\
\text { a foreign language at the level of B-2 or } \\
\text { more higher }\end{array}$ & 3.1 & 3.3 \\
\hline 5. & $\begin{array}{l}\text { Knowledge of a foreign language which } \\
\text { provides access to gain new professional } \\
\text { information }\end{array}$ & 3.6 & 3.2 \\
\hline 6. & $\begin{array}{l}\text { My future well-being will depend on my } \\
\text { knowledge of a foreign language }\end{array}$ & 6.1 & 6.3 \\
\hline 7. & $\begin{array}{l}\text { A great desire to work in a foreign com- } \\
\text { pany or abroad after graduating from } \\
\text { higher educational establishment }\end{array}$ & 6.8 & 7.0 \\
\hline 8. & $\begin{array}{l}\text { A great desire to know a foreign lan- } \\
\text { guage just in any case of a student's life }\end{array}$ & 0.3 & 0.5 \\
\hline 9. & Constantly receive a scholarship & 6.5 & 6.6 \\
\hline 10. & $\begin{array}{l}\text { To get parental and environmental appro- } \\
\text { val }\end{array}$ & 3.4 & 3.8 \\
\hline $\mathbf{1 1 .}$ & Do not lag behind classmates & 4.1 & 4.0 \\
\hline
\end{tabular}

CC Ivashkevych Ernest

DOI (article): https://doi.org/10.32626/2227-6246.2021-52.84-105 


\begin{tabular}{|l|l|c|c|}
\hline \multirow{2}{*}{ No } & \multicolumn{1}{|c|}{ Motives } & \multicolumn{2}{c|}{ The average score } \\
\cline { 3 - 4 } & $\begin{array}{c}\text { Experimen- } \\
\text { tal groups }\end{array}$ & $\begin{array}{c}\text { Control } \\
\text { groups }\end{array}$ \\
\hline 12. & $\begin{array}{l}\text { To achieve respect from the side of tea- } \\
\text { chers }\end{array}$ & 5.5 & 3.7 \\
\hline 13. & To be the example to classmates & 5.8 & 5.2 \\
\hline 14. & $\begin{array}{l}\text { To avoid condemnation and punishment } \\
\text { for poor foreign language learning }\end{array}$ & 2.4 & 1.5 \\
\hline \multicolumn{2}{|c|}{ Overall level of motivation } & 4.65 & 4.48 \\
\hline
\end{tabular}

It should be noted that the vast majority of students in experimental and control groups considered it necessary to appreciate the professional motives of educational activities, although in fact few of them seriously considered the capabilities of a highly qualified specialist with foreign language and translation skills. Since the professional motives of educational activities contribute to the achievement of the ultimate goals of learning, motivation will greatly facilitate the formation of persons' professional orientation.

More important for students there are educational and cognitive motives: to study successfully, to receive good and high grades in academic subjects, to be constantly ready for classes. In this case, it should be noted that for students with good language skills, these motives are less significant than for students with low levels of language skills. This can be explained by the fact that the student feels more confident in terms of success in learning a foreign language. Others try to correct their situation and close the gaps in knowledge that are appeared for one reason or another one during the study of a foreign language at school.

\section{Conclusions}

The professional development of a future specialist is a complex integrative process that involves the use of various forms, tools and methods of facilitative influence on a stu(C) Ivashkevych Ernest

DOI (article): https://doi.org/10.32626/2227-6246.2021-52.84-105 
dent's personality. In order to select and justify the feasibility of using such forms, tools and methods, etc., we describe a conceptual model of the professional development of a future translator. This model, in turn, requires special development, description and analysis of its constituents due, first of all, to its integrity, multicomponent and polyfunctionality.

The sense of the category "professional development» can be found in the paradigm of its comparison with the fundamental scientific categories «the development» and "the formation». The development is defined as the objective process of internal consistent quantitative personal change. Professional development involves the inclusion of a person into the functioning of a new social environment, which is characterized by certain norms of communication, behavior, values, moral and ethical norms and some others. Interpersonal relationships that are developed in the professional team, largely determine the course of the professional adaptation of a man, the formation of his / her social status. Therefore, the components of the professional development should include socio-psychological features that determine a person's place in a professional group, his / her social status.

Professional development is seen as a long-term process of mastering the profession. Scientists believe that professional formation can be represented in two ways: according to the scheme of the process (as a temporary sequence of stages, periods, parts) and by the structure of the activity (as a set of methods and means, the observance of which one after the other person has not a temporary but a paradigm-purpose determination. Professional development should also be understood as the formation of professional competence, as the process of mastering the means of solving professional and pedagogical tasks and problems, as well as models of their solution, etc.

Thus, the professional development of a person is a holistic, dynamic process well organized in time, characterized primarily by the formation of professional intentions, then - by

(C) Ivashkevych Ernest

DOI (article): https://doi.org/10.32626/2227-6246.2021-52.84-105 
DOI: https://doi.org/10.32626/2227-6246.2021-52

2021. випуск 52

the acquisition of knowledge and mastery of skills and abilities, and so to a full realization of oneself in creative pedagogical activity. The main contradiction of professional formation is, as a rule, the contradiction between well-developed personality traits and the objective requirements of leading activity, the significance of which is that it largely determines the further development of the individual as a subject of professional activity. Realizing himself / herself in the process of leading activity, the person gradually changes, which leads to the restructuring of the motives of his / her own professional activity, the formation of new personal characteristics, qualities and traits.

If we take into account the positions of socio-cultural approach in psychology, then the professional formation is directed, first of all, at a specialist in the paradigm of cross-cultural space. Therefore, the professional formation of a future specialist is, first of all, a process of forming a student as a Person of general and professional culture, which ensures his / her general functioning in the surrounding world and the space of our professional activity.

It should be in our mind that the process of professional development is closely related to the formation of professional readiness of a specialist to perform future activities. The structure of professional readiness includes a positive attitude of the individual to his / her future profession, fairly stable motives for future activities, professionally significant personal qualities, professional knowledge, skills and abilities, as well as some experience of their application in practice. Thus, for the professional development of the person it is important for future professionals to master the norms, standards of the profession, the necessary professional personal qualities, knowledge and skills which a specialist needs to successfully solve professional problems, form a motivational and valuable attitudes to their profession, awareness and implementation (C) Ivashkevych Ernest

DOI (article): https://doi.org/10.32626/2227-6246.2021-52.84-105 
areas of their immediate professional development, willingness to carry out a differentiated assessment of the activities having been performed, a combination of professional openness, the ability to learn and provide independent creative pursuits.

In this article the professional development of future specialists is considered from the standpoint of the cultural approach. So, it is a process of forming the person's personal and professional position of the individual, taking into account the diversity of subjective and objective factors, which involve the implementation of strategies for managing the personal resources which are necessary for professional activities on the professional level. It was noted that the professional development of the future specialist also involved the formation of personally significant position, which was understood by us as a system of dominant values-semantic attitudes of a specialist to the socio-cultural environment, of himself / herself and his / her activities.

It was stated that that conceptual model would necessarily include professional readiness for performing the activity. Willingness is characterized by the different nature of the interconnections of its structural components (a cognitive component - knowledge of a foreign language, a linguistic one - linguistic competence, the component of implementation - communication skills). Considering the readiness of a student as a component of person's intercultural communication as a set of individually significant psychological factors of a specialist, (taking into account the diagnostic goals) we have identified the characteristics of different levels of the development of each of the factors of readiness, which we mean as a criterion basis for studying the phenomenon of students' readiness for organizing the process of successful intercultural communication. The first (a cognitive) component is considered in the context of this study as varying levels of foreign language acquisition. In fact, in our opinion, a cognitive component of

(C) Ivashkevych Ernest

DOI (article): https://doi.org/10.32626/2227-6246.2021-52.84-105 
DOI: https://doi.org/10.32626/2227-6246.2021-52

2021. випуск 52

readiness contains the linguistic competence of the person, as well as his / her communicative skills and the peculiarities of using them in the process of professional activity. All these tasks will be solved in our further researches.

\section{Literature}

Варбан М. Ю. Рефлексия профессионального становления в студенческие годы: дис. ... канд. психол. наук: 19.00.01. Самара, 1998. 181 с.

Гончарук Наталія, Онуфрієва Ліана. Психологічний аналіз рівнів побудови комунікативних дій. Psycholinguistics. Психолінгвістика. Психолингвистика. 2018. Вип. 24 (1). С. 97-117. DOI 10.31470/ 2309-1797-2018-24-1-97-117.

Кун М., Макпартленд Т. Тест «Кто Я?». 2019. URL : vsetesti.ru/424.

Максименко С., Ткач Б., Литвинчук Л., Онуфрієва Л. Нейропсихолінгвістичне дослідження політичних гасел із зовнішньої реклами. Psycholinguistics. Психолінгвістика. Психолингвистика. 2019. Вип. 26 (1). С. 246-264. DOI 10.31470/2309-1797-2019-26-1246-264. URL : https://psycholing-journal.com/index.php/journal/ article/view/715.

Методика Х. Хекхаузена «Мотиваційні тенденції особистості». 2019. URL : https://murzim.ru/psihologija/psihologija-izuchenijalichnosti/10555-diagnostika-motivacii-po-testu-x-hekhau zena.html.

Batel, E. (2020). Context Effect on L2 Word Recognition: Visual Versus Auditory Modalities. Journal of Psycholinguist Research, 49, 223245. URL : https://doi.org/10.1007/s10936-019-09683-6.

Mykhalchuk, N., \& Bihunova, S. (2019). The verbalization of the concept of «fear» in English and Ukrainian phraseological units. Cognitive Studies | Études cognitives, 19, 11. Варшава (Польща). URL : https://doi.org/10.11649/cs.2043.

Mykhalchuk, N., \& Ivashkevych, E. (2019). Psycholinguistic Characteristics of Secondary Predication in Determining the Construction of a Peculiar Picture of the World of a Reader. Psycholinguistics. Психолінгвістика. Психолингвистика, 25 (1), 215-231. DOI 10.31470/2309-1797-2019-25-1-215-231.

Ryan, R., \& Deci, E. (2000). Self-determination Theory and the Facilitation of Intrinsic Motivation, Social Development, and Well-being. American Psychologist, 55 (1), 68-78.

Scharle, Agota, \& Szabó, Anita (2000). Learner autonomy. A guide to developing learner responsibility. Cambridge : Cambridge University Press. 124 p.

(C) Ivashkevych Ernest

DOI (article): https://doi.org/10.32626/2227-6246.2021-52.84-105 


\section{References}

Varban, M. Yu. (1998). Refleksiia professionalnogo stanovleniia v studencheskiie gody [The reflection of the professional development in the student years]. Candidate's thesis. Samara [in Russian].

Goncharuk, Nataliia, \& Onufriieva, Liana (2018). Psykholohichnyi analiz rivniv pobudovy komunikatyvnykh dii [Psychological analysis of the levels of construction of communicative actions]. Psycholinguistics. Psykholinhvistyka. Psikholingvistika - Psycholinguistics. Psycholinguistics. Psycholinguistics, 24 (1), 97-117. DOI 10.31470/23091797-2018-24-1-97-117 [in Ukrainian].

Kun, M., \& McPartland, T. (2019). Test «Kto Ya?» [The questionnaire "Who am I?»]. Retrieved from vsetesti.ru/424 [in Russian].

Maksymenko, S., Tkach, B., Lytvynchuk, L., \& Onufriieva, L. (2019). Neiropsykholinhvistychne doslidzhennia politychnykh hasel iz zovnishnoi reklamy [A neuropsycholinguistic research of political slogans from outdoor advertising]. Psycholinguistics. Psykholinhvistyka. Psikholingvistika - Psycholinguistics. Psycholinguistics. Psycholinguistics, 26 (1), 246-264. DOI 10.31470/2309-1797-2019-26-1-246264. Retrieved from https://psycholing-journal.com/index.php/ journal/article/view/715 [in Ukrainian].

Metodika Kh. Khekhauzena "Motyvatsiini tendentsii osobystosti» [The questionnaire of Kh. Kheckhausen "Motivational tendencies of the personality»] (2019). Retrieved from https://murzim.ru/ psihologija/psihologija-izuchenija-lichnosti/10555-diagnostikamotivacii-po-testu-x-hekhau zena.html [in Ukrainian].

Batel, E. (2020). Context Effect on L2 Word Recognition: Visual Versus Auditory Modalities. Journal of Psycholinguist Research, 49, 223245. Retrieved from https://doi.org/10.1007/s10936-019-09683-6.

Mykhalchuk, N., \& Bihunova, S. (2019). The verbalization of the concept of «fear» in English and Ukrainian phraseological units. Cognitive Studies $\mid$ Études cognitives, 19, 11. Warsaw (Poland). Retrieved from https://doi.org/10.11649/cs.2043.

Mykhalchuk, N., \& Ivashkevych, E. (2019). Psycholinguistic Characteristics of Secondary Predication in Determining the Construction of a Peculiar Picture of the World of a Reader. Psycholinguistics. Psykholinhvistyka. Psikholingvistika - Psycholinguistics. Psycholinguistics. Psycholinguistics, 25 (1), 215-231. DOI 10.31470/2309-17972019-25-1-215-231.

Ryan, R., \& Deci, E. (2000). Self-determination Theory and the Facilitation of Intrinsic Motivation, Social Development, and Well-being. American Psychologist, 55 (1), 68-78.

(C) Ivashkevych Ernest

DOI (article): https://doi.org/10.32626/2227-6246.2021-52.84-105 
DOI: https://doi.org/10.32626/2227-6246.2021-52

2021. випуск 52

Scharle, Agota, \& Szabó, Anita (2000). Learner autonomy. A guide to developing learner responsibility. Cambridge : Cambridge University Press.

Івашкевич Ернест. Психологічні основи зв'язку між автономією студента і мотивацією учіння

\section{АНОТАЦІЯ}

Мета дослідження - показати зв'язок між автономією особистості й мотивацією учіння, забезпечити дослідження підструктур мотиваційного компонента професійної компетентності студентів.

Методи дослідження. Щодо загальнонаукових методів, то використано такі з них, як індукція, дедукція, аналіз і синтез, методи порівняння й опису, метод обгрунтування тощо. Також було використано експериментальний метод: констатувальне дослідження. Застосовано такі психодіагностичні методики, як: тест "Хто Я?» (М. Кун і Т. Мак-Партленд), методики "Мій шлях у профресію» та "Піраміда професійного зростання» (М. Ю. Варбан), методику Х. Хекхаузена «Мотиваційні тенденції особистості».

Результати дослідження. Зазначимо, що переважна більшість студентів експериментальних і контрольних груп вважала для себе обов'язковим високо оцінити професійні мотиви навчальної діяльності, хоча насправді небагато хто з них серйозно задумувався над тим, які можливості має висококваліфікований фахівець зі знанням іноземної мови та сформованими навичками здійснення професійної діяльності. Оскільки профресійні мотиви навчальної діяльності сприяють досягненню кінцевих цілей навчання, то мотивація великою мірою фасилітуватиме формування профресійної спрямованості.

Більш значущими для студентів є навчально-пізнавальні мотиви: успішно вчитися, отримувати хороші та високі оцінки з навчальних предметів, бути постійно готовими до занять. У цьому плані варто зазначити, що для студентів із хорошою мовною підготовкою ці мотиви є менш значущими, ніж для студентів із низьким рівнем мовної підготовки. Це можна пояснити тим, що перші почуваються впевненішими з огляду на досягнення успіху в процесі вивчення іноземної мови. Другі ж намагаються виправити своє становище й ліквідувати прогалини в знаннях, які з'явились з тієї чи іншої причини під час вивчення іноземної мови у школі. (C) Ivashkevych Ernest

DOI (article): https://doi.org/10.32626/2227-6246.2021-52.84-105 
DOI: https://doi.org/10.32626/2227-6246.2021-52

2021. ВИПУСК 52

Висновки. Професійне становлення майбутнього фахівця є складним інтегративним прочесом, що передбачає використання різноманітних форм, засобів і методів фасилітативного впливу на особистість студента. 3 метою відбору й обгрунтування доцільності використання таких форм, засобів і методів тощо, в наступних наших дослідженнях доцільно описати концептуальну модель професійного становлення майбутнього фахівця. Ця модель, своєю чергою, вимагає спеціальної розробки, опису й аналізу їі складових у силу, насамперед, своєї цілісності, багатокомпонентності та поліфункціональності.

Сутність категорії «професійне становлення» може бути виявлена у парадигмі ї̈ зіставлення з фундаментальними науковими категоріями «розвиток» $i$ «формування». Розвиток визначається як об'єктивний процес внутрішнього послідовного кількісного і якісного особистісного змінювання. Професійне становлення передбачає включення людини у функціонування нового соціального середовища, що характеризується певними нормативами спілкування, поведінки, цінностями, морально-етичними нормами тощо. Міжособистісні відносини, що складаються у професійному колективі, багато в чому визначають хід професійної адаптації людини, формування ії соціального статусу. Тому до складових професійного становлення мають бути включені й соціально-психологічні особливості, що визначають місце людини у професійній групі, ії соціальний статус.

Ключові слова: автономія студента, мотивація, міжособистісні стосунки, цілі навчання, формування професійної орієнтації особистості, професійний розвиток.

\section{Ивашкевич Эрнест. Психологические основы связи между автономией студента и мотивацией учения}

\section{АННОТАЦИЯ}

Цель исследования - показать связь между автономией личности и мотивацией учения, обеспечить исследование подструктур мотивационного компонента профессиональной компетентности студентов.

Методы исследования. Из совокупности основных научных методов были использованы такие из них, как индукция, дедукция, анализ и синтез, методы сравнения и описания, метод обоснования. Также был использован экспериментальный метод: констатирующий эксперимент.

(C) Ivashkevych Ernest

DOI (article): https://doi.org/10.32626/2227-6246.2021-52.84-105 
Применены следующие психодиагностические методики: тест «Кто Я?» (М. Кун и Т. Мак-Партленд), методики «Мой путь в профессию» и «Пирамида профессионального роста» (М. Ю. Варбан), методика Х. Хекхаузена "Мотивационные тенденции личности».

Результаты исследования. Доказано, что подавляющее большинство студентов экспериментальных и контрольных групп считали для себя обязательным высоко оценить профессиональные мотивы учебной деятельности, хотя на самом деле немногие из них серьезно задумывались над тем, какие возможности имеет высококвалифицированный специалист со знанием иностранного языка и сформированными навыками осуществления профессиональной деятельности. Поскольку профессиональные мотивы учебной деятельности способствуют достижению конечных целей обучения, то мотивация во многом фасилитирует формирование профессиональной направленности личности.

Более значимыми для студентов являются учебно-познавательные мотивы: успешно учиться, получать хорошие и высокие оценки по учебным предметам, быть постоянно готовыми к занятиям. В этом плане стоит отметить, что для студентов с хорошей языковой подготовкой эти мотивы являются в меньшей степени значимыми, чем для студентов с низким уровнем языковой подготовки. Это можно объяснить тем, что первые чувствуют себя более уверенными, учитывая пути достижения успеха в процессе изучения иностранного языка. Вторые же пытаются исправить свое положение и ликвидировать пробелы в знаниях, появившиеся по той или иной причине при изучении иностранного языка в школе.

Выводы. Профессиональное становление будущего специалиста является сложным интегративным процессом, который предусматривает использование разнообразных форм, средств и методов фасилитативного воздействия на личность студента. С целью отбора и обоснования целесообразности использования таких форм, средств и методов работы, необходимо в перспективе описать концептуальную модель профрессионального становления будущего специалиста. Эта модель, в свою очередь, требует специальной разработки, описания и анализа ее составляющих в силу, прежде всего, своей целостности, многокомпонентности и полифункциональности.

Сущность категории "профессиональное становление» может быть рассмотрена в парадигме ее сопоставления с фундаментальными () Ivashkevych Ernest

DOI (article): https://doi.org/10.32626/2227-6246.2021-52.84-105 
DOI: https://doi.org/10.32626/2227-6246.2021-52

2021. ВИПУСК 52

научными категориями «развитие» и "формирование». Развитие определяется как объективный процесс внутреннего последовательного количественного и качественного личностного изменения. Профессиональное становление предполагает включение человека в поле функционирования новой социальной среды, характеризующейся определенными нормативами общения, поведения, иенностями, морально-этическими нормами. Межличностные отношения, складывающиеся в профессиональном коллективе, во многом определяют ход профессиональной адаптации человека, формирования его социального статуса. Поэтому к составляющим профрессионального становления должны быть отнесены и социально-психологические особенности, определяющие место человека в профессиональной группе, его социальный статус.

Ключевые слова: автономия студента, мотивачия, межличностные отношения, цели обучения, формирование профессиональной ориентации личности, профрессиональное развитие.

Original manuscript received February 19, 2021 Revised manuscript accepted March 24, 2021 